\title{
FACTOR ANALYSIS APPLIED TO METAL CONTENT IN HAIR: A STUDY ON THE CORRELATION BETWEEN NEIGHBORHOODS AND ASSOCIATED RISK - ALTAMIRA, PARÁ, BRAZIL
}

\section{Pedro Moreira Sousa Junior ${ }^{*}$, Simone Fátima Pinheiro Pereira ${ }^{2}$, Ronaldo Magno Rocha ${ }^{3}$, Orivan Maria Marques Teixeira ${ }^{4}$ Mateus Higo Daves Alves ${ }^{1}$, Luciana Pinheiro Santos ${ }^{2}$, Auriane Consolação da Silva Gonçalves4, Daniel Pinheiro Nogueira², and Kelson do Carmo Freitas Faial 5}

${ }^{1}$ Universidade Federal Rural da Amazônia, Av. Barão de Capanema, S/N, 68.700-665, Capanema, Pará, Brasil; ${ }^{2}$ Laboratório de Química Analítica e Ambiental, Universidade Federal do Pará, Rua Augusto Correa, S / N - Guamá, 66075-900 - Belém PA - Brasil; ${ }^{3}$ Laboratório Central da Secretaria de Saúde do Pará, Rua Augusto Montenegro, 524 - Parque Guajará, 66823010 - Belém - PA - Brasil; " ${ }^{4}$ Empresa Brasileira de Pesquisa Agropecuária, Trav. Enéas Pinheiro, S/N, Bairro Marco, 66095-

100.Belém, Pará, Brasil; ${ }^{5}$ Instituto Evandro Chagas, Laboratório de Meio Ambiente, Rod. Br 316, Km 7, S/N, Bairro Levilândia, 67030-000 Ananindeua, Pará, Brasil

\section{ARTICLE INFO}

\section{Article History:}

Received $20^{\text {th }}$ December, 2020

Received in revised form

$10^{\text {th }}$ December, 2020

Accepted $21^{\text {st }}$ January, 2021

Published online $24^{\text {th }}$ February, 2021

Key Words:

Toxic risk, Hair, Principal Component Analysis.

*Corresponding author:

Pedro Moreira Sousa Junior

\begin{abstract}
Few studies on capillary metals are conducted in the Amazon region despite the diversity of environmental problems that directly reflect on human health, as is the case of the population of Altamira. The hair matrix was selected because it is an indicator of past exposure, which enablesto correlate the concentration of trace elements in neighborhood residents in the metropolitan region to identify grouping by chemical similarities, using factor analysis as a statistical technique. The city was chosen due to its regional importance and the intense transformation process undergone over the years, among them the implantation of the Belo Monte Hydroelectric Plant, gold mining, and agriculture. These events brought development linked to social, environmental, and public health problems for the municipality. The elements were determined by Inductively coupled plasma atomic emission spectrometry (ICP-AOS). Among the elements surveyed, $\mathrm{Mn}, \mathrm{Ba}, \mathrm{Sr}, \mathrm{Ca}, \mathrm{Mg}$, and $\mathrm{Al}$ stood out as the most important and responsible for the grouping of neighborhoods, with an explanation percentage of $76.08 \%$. The elements $\mathrm{Mn}, \mathrm{Ba}, \mathrm{Sr}, \mathrm{Ca}$, and $\mathrm{Mg}$ are responsible for grouping the neighborhoods Esplanada do Xingu, Açaizal, Aparecida, Centro, Jardim Independente I and II, Sudam I and II, Jardim Oriente, and Jardim dos Estados with $58.96 \%$ of varianceexplained, and Al for the neighborhoods São Sebastião and Catedral with $17.12 \%$ of variance explained. These results indicated that the first group has a risk associated with the metals $\mathrm{Mn}$ and $\mathrm{Ba}$, whereas the second with the metal $\mathrm{Al}$, all with relevant toxic potential. Signs of health problems may be being demonstrated, as these results refer to extemporaneous exposure.
\end{abstract}

Copyright () 2021, Pedro Moreira Sousa Junior et al., This is an open access article distributed under the Creative Commons Attribution License, which permits unrestricted use, distribution, and reproduction in any medium, provided the original work is properly cited.

Citation: Pedro Moreira Sousa Junior, Simone Fátima Pinheiro Pereira, Ronaldo Magno Rocha, Orivan Maria Marques Teixeira Mateus Higo Daves Alves, Luciana Pinheiro Santos, Auriane Consolação da Silva Gonçalves, Daniel Pinheiro Nogueira and Kelson do Carmo Freitas Faial, 2021. "Factor analysis applied to metal content in hair: a study on the correlation between neighborhoods and associated risk - Altamira, Pará, Brazil", International Journal of Development Research, 11, (02), 44409-44414

\section{INTRODUCTION}

Currently, the biological monitoring of chemical elements has become an important tool in the scientific environment, as it allows investigative studies of harmful substances and their correlation with epidemics, pandemics, or even occupational exposures, especially in areas of high demographic density. The danger of trace elements is associated with their physical-chemical properties and routes of exposure.
This combination linked to the health condition and inherent vulnerability are the main factors that cause generalized problems to the population (Ali et al., 2019; Gil and Hernández, 2015). Toxic metals and metalloids are contaminants of great importance because they are widely distributed in air, water, soil and, other environmental compartments resulting from anthropogenic or geological emissions (Gupta, 2019). In this perspective, analyzes in hair samples stand out as the most used due to simplicity, little invasiveness, high sample mineralization, and irreversible incorporation of trace elements in this 
matrix (Chojnacka et al., 2006; Kosanovic and Jokanovic, 2011; Skalny et al., 2015). The city of Altamira, $720 \mathrm{~km}$ from Belém, is the most important city located in the Xingu region. Over the last 30 years, Altamira has been the scene of an intense migratory flow, with the propelling agents of mining, agriculture, and more recently the Belo Monte Hydroelectric Plant (Miranda Neto and Herrera, 2016). All this transforming process in the region brings advances, but also socio-environmental problems that mainly affect the biodiversity, food, and life quality (Gauthier and Moran, 2018). Given the above, studies on the influence of trace metals on the population living in the metropolitan region of Altamira become relevant. The use of the Factor Analysis emerges as an important tool in the selection of neighborhood groups and in the indication of which metals are important in the explanation of that behavior.

\section{MATERIALS AND METHODS}

Characteristics of the study area: Altamira stands out as one of the most important cities in Pará, according to IBGE data from 2014, the municipality of Altamira had an estimated population of 106,768 inhabitants, whereas in the 2010 Census the population was 99,075 inhabitants, and in 2000 its population was 77,439 inhabitants. This growth was driven by two factors: the first refers to the gold extraction and trading activities that started in the 1980s (Macedo, 2016), and the migration process due to the Belo Monte Hydroelectric Plant (Miranda Neto and Herrera, 2016). The population weight is relevant regarding the role played by Altamira, because according to the main theories of urban location, activities related to the supply of goods and services tend to be concentrated in urban centers, causing serious problems of urban and social infrastructure (Franco et al., 2018).

Sampling: The sampling was simple and random, contemplating a universe of 70 individuals of different ages, in a sample space of 14 neighborhoods (São Sebastião, Açaizal, Aparecida, Brasília, Catedral, Centro, Esplanada do Xingu, Jardim Independente I and II, Jardim dos Estados, Jardim do Oriente, Liberdade, and Sudam I and II), which were chosen considering the population density parameter (IBGE, 2014). In this study, all the ethical procedures foreseen in the Declaration of Helsinki and the Brazilian legislation were carried out, including the Free and Informed Consent Term (TCLE) according to the protocol of the internal ethics committee of the Federal University of Pará. All residences visited were georeferenced and the extraction of the hair sample occurred in only one volunteer member per household to which the TCLE was issued. The sample space where the study was developed is illustrated in Figure 1.

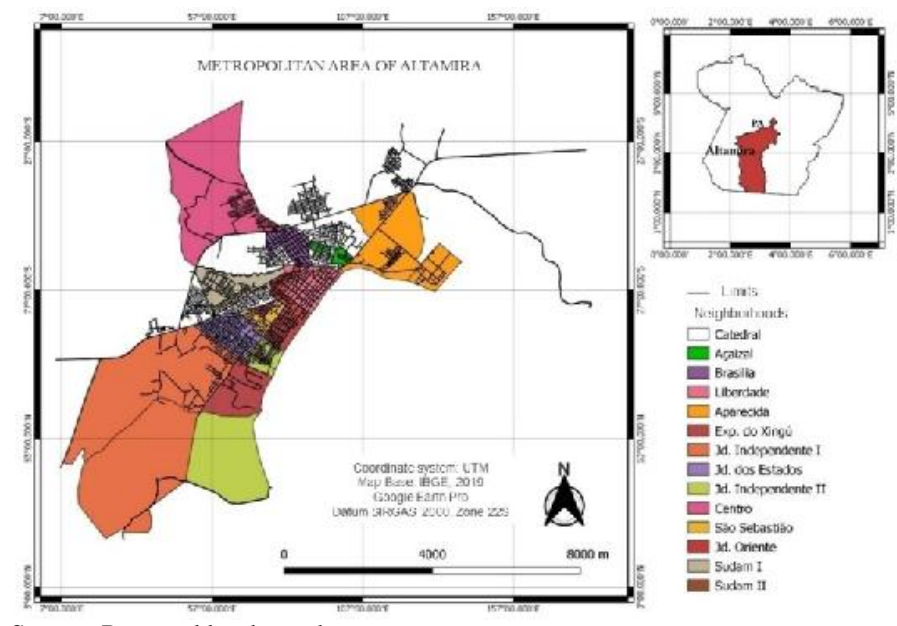

Source: Prepared by the authors.

Figure 1. Map of the metropolitan area of Altamira highlighting the neighborhoods sampled in the survey

Collection: The samples were collected on the nape of the neck (Katz and Chatt, 1988; Robbins and Robbins, 2012). This collection site is already standardized because it is less susceptible to external contamination, in addition to being the area that is more likely to have hair, even in bald individuals. Pozebon et al. (1999) and Wang et al. (2019) recommend that the sample be collected respecting the range from $0.5 \mathrm{~cm}$ to $1.0 \mathrm{~cm}$ in length, avoiding aesthetic damage. To determine the amount of metals Manganese $(\mathrm{Mn})$, Barium $(\mathrm{Ba})$, Strontium ( $\mathrm{Sr})$, Iron $(\mathrm{Fe})$, Calcium $(\mathrm{Ca})$, Magnesium $(\mathrm{Mg})$, Sodium $(\mathrm{Na})$, Aluminum (Al), Zinc ( $\mathrm{Zn})$, and Potassium $(\mathrm{K})$, it is suggested between 1 to $2 \mathrm{~g}$ of hair extracted with the aid of gloves and titanium or stainless steel scissors (Semenova et al., 2019). The hair sample must be identified and conditioned in a plastic bag or polyethylene bottle and sent to the laboratory where the analyzes will be performed. Hair with different (natural) pigmentations from the same individual must be collected separately, since the absorption of the elements may vary according to their pigmentation (Pozebon et al., 1999; Marcineck-Jacel et al., 2017; Li et al., 2020).

Sample pre-treatment: All samples were treated analytically in the Analytical and Environmental Chemistry Laboratory (LAQUANAM) at the Federal University of Pará, Brazil. The pre-treatment consisted of washing the samples with non-ionic detergent and then submitting to the procedure deionized water/acetone/deionized water for 10 minutes in each step, for complete removal of external contamination, as described by Drobyshev et al. (2017) and Ali et al. (2019). In the next stage, the samples were conditioned in an oven at $50^{\circ} \mathrm{C}$ for 2 hours and then crushed with a stainless steel instrument until fragments were smaller than $1 \mathrm{~cm}$ (Sela et al., 2007).

Instrumental analytical procedures: In this stage, the samples were microwave digested in $6 \mathrm{ml}$ polytetrafluoroethylene (PTFE) containers with mixtures of $2 \mathrm{ml}$ of concentrated $\mathrm{HNO}_{3}$ and $0.25 \mathrm{ml}$ of concentrated $\mathrm{H}_{2} \mathrm{O}_{2}$ (Pereira et al., 2009; Tipple et al., 2013; Hu et $a l ., 2019)$. The equipment used in the digestion procedure is the PROVECTO ANALÍTICA brand and model DGT 100 Plus. The recommended program was followed (Tipple et al., 2013), which is heating at $200^{\circ} \mathrm{C}$ at a rate of $13.3 \mathrm{C} / \mathrm{min}$ and maintained for $15 \mathrm{~min}$. After the cooling step, the sample was reduced to $2 \mathrm{~mL}$, transferred to a $10 \mathrm{~mL}$ volumetric flask, calibrated with pure water, and transferred to a $15 \mathrm{~mL}$ Falcon tube, for later analysis of the metals. The technique used was Inductively coupled plasma optical emission (ICP OES) due to its high sensitivity, low detection and quantification limits, and, mainly, to enable multi-element analysis (Skoog et al., 2008). The equipment used for quantifying the elements is from the Varian brand (PRO view model). The calibration and analysis methodology followed the manufacturer's instructions (Charles and Fredeen, 1997; Pereira et al, 2007). The initial specifications of the equipment can be observed in Table 01. The study of accuracy and precision was performed with analysis of the standard hair reference material (GBW07601 of the China National Analysis Center) (Hair et al., 2009). In general, the quantification of all trace elements (Mn, Ba, Sr, $\mathrm{Mn}, \mathrm{Fe}, \mathrm{Ca}, \mathrm{Mg}, \mathrm{Na}, \mathrm{Al}$, and $\mathrm{Zn}$ ) performed in this study presented a recovery rate $(95.3-101.0 \%)$ in the reference standard. The recovery after digested solution showed an interval between 96 and $100.0 \%$ with the acceptable precision level in a range of \pm 5 in weight $\%$. The calibration curves were linear within the range ( $r$ 0.99) demonstrating the precision and consistency of technical analysis for determining the analytes. The descriptive data for this stage were analyzed using the software SPSS ${ }^{\circledR}$ version 21.

Results Analysis and Interpretation: The analytical results were treated statistically with the help of SPSS ${ }^{\circledR}$ software version 21 for Windows (Statistical Package for the Social Sciences, Inc.). In the preliminary study, the methods of descriptive analysis were used, evaluating the mean and standard deviation, in addition to the bivariate correlation, seeking the strongest interactions in the data set. Both methods corroborate practices developed by Ballesteros et al. (2017) and suggested by Hair et al. (2009). Regarding the Factor Analysis, the Kaiser-Meyer-Olkin (KMO) tests were performed to assess the proportion of variance that the parameters present between themselves, assuming reasonable $\mathrm{KMO}$ values between 0.6 and 0.7 , average values between 0.7 and 0.8 , good values between 0.8 and 0.9 , and very good values greater than 0.9 (Hair et al., 2009; Dini et al., 2014). Figueiredo Filho and Silva (2010) suggests the need to use 
Bartlett's test of sphericity to verify the possibility of the matrix is identity and the condition for non-occurrence, and Bartlett's significance value is less than 0.05 . Although there is no consensus on patterns of variance and commonality, authors report that to ensure more robust results in Principal Component Analysis (PCA), the cumulative explanation variance must present values above $60 \%$ and communalities greater than 0.6 to certify that the variable is representative in the data matrix (Hair et al., 2009; Dini et al., 2014; Li et al., 2020; Kumar et al., 2019).

\section{RESULTS AND DISCUSSION}

Univariate statistics: Univariate statistical tests are important because they allow an overview of the individual behavior of the variables. The descriptive analysis explains the average levels and their variability and thus identifies whether there is a homogeneous or heterogeneous sampling behavior. samples. The high amplitude in the sample results is due to environmental factors such as exposure to contaminated environments (place of residence or work), eating habits with food intake from the bioaccumulation chain, to biologicals conditions where the differentiated physiology between male and female stands out concerning the absorption of chemical elements (Miekeley et al., 1998; Abdulrahman et al., 2012; Gibb et al. 2016, Ali et al., 2019). Another important piece of information deals with the groupings discretized according to the variables. The contents of $\mathrm{Ba}, \mathrm{Fe}, \mathrm{Ca}$, and $\mathrm{Al}$ are responsible for grouping most of the neighborhoods (S. Sebastião, Esp. Dos Xingu, Liberdade, Açaizal, Aparecida, Catedral, Independent Jd. II, and Jd. Oriente); $\mathrm{Sr}$ e $\mathrm{Mg}$ integrates the neighborhoods São Sebastião, Esp. do Xingu, and Liberdade; Zn and the neighborhoods S. Sebastião, Esp. Dos Xingu, Liberdade, Aparecida, Catedral, Jd. Independent I and II, Jd. Oriente, and Centro; and the metals $\mathrm{Na}$ and $\mathrm{K}$ did not show any influence on the neighborhood grouping. The parameters $\mathrm{Mn}, \mathrm{Ba}, \mathrm{Ca}$, and $\mathrm{Mg}$ showed the highest bivariate correlations (sig. <0.05) (Table 3).

Table 1. ICP-OES parameters for hair elements analyzes

\begin{tabular}{|l|c|}
\hline Parameters & Value \\
\hline Radiofrequency power $(\mathrm{KW})$ & 1.4 \\
\hline Nebulizer pressure (KPa) & 180 \\
\hline Plasma argon flow-rate (L/min) & 15 \\
\hline Auxiliary argon flow-rate (L/min) & 0.75 \\
\hline Sample introduction (s) & 40 \\
\hline Washing time (s) & 30 \\
\hline Stabilization time (s) & 15 \\
\hline Read time (s) & 1 \\
\hline Peristaltic pump speed (rpm) & 15 \\
\hline
\end{tabular}

Table 2. Descriptive statistics of metal contents $(\mu \mathrm{g} / \mathrm{g})$ discretized by neighborhood

\begin{tabular}{|c|c|c|c|c|c|c|c|c|c|c|}
\hline \multicolumn{2}{|l|}{ Neighborhood } & $\mathrm{Ba}$ & $\mathrm{Sr}$ & $\mathrm{Fe}$ & $\mathrm{Ca}$ & $\mathrm{Mg}$ & $\mathrm{Na}$ & $\mathrm{Al}$ & $\mathrm{Zn}$ & $\mathrm{K}$ \\
\hline \multirow[t]{2}{*}{ S. Sebastião } & Mean & 14.02 & 4.95 & 26.27 & 676.43 & 78.91 & 164.89 & 45.28 & 429.73 & 26.27 \\
\hline & S. D. & 19.17 & 2.68 & 15.22 & 270.79 & 42.75 & 87.29 & 28.41 & 595.92 & 15.22 \\
\hline \multirow[t]{2}{*}{ Esp. do Xingu } & Mean & 4.82 & 3.11 & 19.67 & 567.63 & 69.65 & 113.68 & 16.10 & 136.16 & 19.67 \\
\hline & S. D. & 4.02 & 1.35 & 7.74 & 193.14 & 51.44 & 88.79 & 6.22 & 44.41 & 7.74 \\
\hline \multirow[t]{2}{*}{ Liberdade } & Mean & 8.20 & 4.04 & 32.96 & 565.54 & 75.78 & 162.28 & 20.13 & 112.87 & 64.45 \\
\hline & S. D. & 4.35 & 2.80 & 18.52 & 350.61 & 64.34 & 108.51 & 11.79 & 31.64 & 36.96 \\
\hline \multirow[t]{2}{*}{ Aparecida } & Mean & 6.59 & 2.37 & 29.76 & 598.19 & 45.10 & 117.66 & 23.20 & 125.16 & 76.96 \\
\hline & S. D. & 8.67 & 1.84 & 22.16 & 312.37 & 42.23 & 47.45 & 8.89 & 33.42 & 72.23 \\
\hline \multirow[t]{2}{*}{ Catedral } & Mean & 22.12 & 7.33 & 27.52 & 908.96 & 146.57 & 171.01 & 29.90 & 134.69 & 96.01 \\
\hline & S. D. & 15.44 & 4.65 & 2.94 & 543.42 & 87.06 & 81.84 & 20.51 & 31.01 & 27.71 \\
\hline \multirow{2}{*}{$\begin{array}{l}\text { Jd. Independente } \\
\text { I e II }\end{array}$} & Mean & 3.56 & 1.60 & 35.96 & 529.10 & 33.25 & 167.22 & 38.68 & 106.40 & 79.09 \\
\hline & S.D. & 1.33 & 0.77 & 27.42 & 264.54 & 14.59 & 76.38 & 26.99 & 43.36 & 19.97 \\
\hline \multirow[t]{2}{*}{ Sudam I e II } & Mean & 7.15 & 1.85 & 29.98 & 288.92 & 27.69 & 95.52 & 14.85 & 77.98 & 42.44 \\
\hline & S. D. & 0.61 & 0.22 & 10.62 & 38.25 & 10.18 & 19.45 & 7.04 & 43.72 & 2.23 \\
\hline \multirow[t]{2}{*}{ Jd. Oriente } & Mean & 7.87 & 2.96 & 18.91 & 689.14 & 104.24 & 277.87 & 39.64 & 192.53 & 120.97 \\
\hline & S. D. & 4.12 & 2.62 & 11.30 & 571.37 & 84.07 & 80.35 & 62.56 & 162.23 & 62.96 \\
\hline \multirow[t]{2}{*}{ Jd. dos Estados } & Mean & 5.74 & 2.08 & 21.79 & 211.82 & 13.05 & 60.73 & 37.87 & 107.01 & 53.80 \\
\hline & S. D. & 8.60 & 2.39 & 23.60 & 270.29 & 22.37 & 52.35 & 16.17 & 29.01 & 25.38 \\
\hline \multirow[t]{2}{*}{ Centro } & Mean & 10.63 & 2.96 & 3.19 & 71.74 & 3.80 & 30.30 & 31.11 & 140.80 & 65.40 \\
\hline & S. D. & 17.16 & 4.74 & 1.94 & 54.36 & 7.16 & 17.85 & 10.96 & 25.69 & 23.20 \\
\hline Mean value & ---- & 9.07 & 3.32 & 24.60 & 510.74 & 59.80 & 136.11 & 29.67 & $\underline{156.33}$ & 64.50 \\
\hline Mean standard deviation & $-\cdots$ & $\underline{8.34}$ & 2.40 & 14.14 & 286.91 & 42.61 & 66.02 & $\underline{19.95}$ & 104.04 & 29.36 \\
\hline Rodushkin and Mikael (2000) & Mean & 1.04 & 2.84 & 13.95 & 1501.50 & 74.75 & 343.50 & 14.15 & 133.00 & 213.70 \\
\hline Goullé et al. (2005) & Mean & 0.81 & 2.40 & --- & --- & --- & --- & 2.78 & 169.00 & --- \\
\hline Batista et al. (2009) & Mean & 1.06 & --- & --- & $-\cdots$ & -- & $-\cdots$ & 3.36 & 142.00 & -- \\
\hline Ballesteros et al. (2017) & Mean & 1.00 & 3.46 & 19.75 & --- & --- & --- & 3.41 & 148.95 & --- \\
\hline Mean value & $-\cdots$ & 0.97 & 2.90 & 16.85 & 1501.50 & 74.75 & 343.50 & 5.92 & 148.23 & 213.70 \\
\hline
\end{tabular}

S. D. - Standard Deviation

The bivariate correlation seeks to identify the direct linear relationships between the variables and the possible existing associations. Evaluating the results of Table 2, the variables Mn (5.74 $\pm 5.06), \mathrm{Ba}(9.07 \pm 8.34), \mathrm{Sr}(3.32 \pm 2.40), \mathrm{Fe}(24,60 \pm 14.14), \mathrm{Ca}$ (510.74 \pm 286.91$), \mathrm{Mg}(59.80 \pm 42.61), \mathrm{Al}(29.67 \pm 19.95)$, and $\mathrm{Zn}$ $(156.33 \pm 104.04)$ stood out for presenting levels above those found by previous studies conducted over approximately 17 years (Rodushkin and Axelsson, 2000; Goullé et al., 2005; Batista et al., 2009; Ballesteros et al., 2017). The considerations regarding this information refer to the high sample variability, indicating that there is no pattern in the content of the elements selected in the hair
This characteristic remains constant in both tests, directing the understanding that they are responsible for most of the explanatory content of the matrix, serving as a statistical method complementary to other techniques such as linear regression or factor analysis (Filippini et al., 2018; Ainley et al., 2020). Rodushkin and Axelsson (2000) report that the first explanatory factor for the interrelation of chemical elements is due to their chemical properties, which highlights the alkaline nature for example, which at that moment, can explain part of the correlation and why they are positive. As it indicates past contamination, other authors suggest that these chemical groups are due to the individual's social condition, whereas 
Table 3. Result of Pearson's bivariate correlation between the variables tested

\begin{tabular}{|c|c|c|c|c|c|c|c|c|c|c|c|}
\hline \multicolumn{2}{|l|}{ Correlation } & $\mathrm{Mn}$ & $\mathrm{Ba}$ & $\mathrm{Sr}$ & $\mathrm{Ca}$ & $\mathrm{Mg}$ & $\mathrm{Al}$ & $\mathrm{Fe}$ & $\mathrm{Na}$ & $\mathrm{Zn}$ & $\mathrm{K}$ \\
\hline \multirow[t]{10}{*}{ Significance of Pearson $(<0.05)$} & $\mathrm{Mn}$ & & & & & & & & & & \\
\hline & $\mathrm{Ba}$ & 0.001 & & & & & & & & & \\
\hline & $\mathrm{Sr}$ & 0.001 & 0.001 & & & & & & & & \\
\hline & $\mathrm{Ca}$ & 0.001 & 0.001 & 0.001 & & & & & & & \\
\hline & $\mathrm{Mg}$ & 0.001 & 0.001 & 0.001 & 0.001 & & & & & & \\
\hline & $\mathrm{Al}$ & 0.410 & 0.058 & 0.107 & 0.007 & 0.269 & & & & & \\
\hline & $\mathrm{Fe}$ & 0.014 & 0.052 & 0.177 & 0.001 & 0.038 & 0.018 & & & & \\
\hline & $\mathrm{Na}$ & 0.234 & 0.322 & 0.447 & 0.003 & 0.001 & 0.369 & 0.187 & & & \\
\hline & $\mathrm{Zn}$ & 0.189 & 0.278 & 0.063 & 0.009 & 0.070 & 0.007 & 0.422 & 0.254 & & \\
\hline & $\mathrm{K}$ & 0.486 & 0.241 & 0.177 & 0.030 & 0.005 & 0.066 & 0.417 & 0.001 & 0.380 & \\
\hline
\end{tabular}

Table 4. Statistical result of matrix adjustment

\begin{tabular}{|l|l|c|}
\hline \multicolumn{2}{|l|}{ KMO and Bartlett tests (Mn, Ba, Sr, Fe, Ca, Mg, Al e Zn) } & Values \\
\hline Kaiser-Meyer-Olkin measure of sampling adequacy. & 0.601 \\
\hline Bartlett's test of Sphericity & Approx. Chi-Square & 222.594 \\
\cline { 2 - 3 } & Significance & 0.050 \\
\hline Commonalities & Fe & $\underline{0.268}$ \\
\hline Teste de KMO e Bartlett (Mn, Ba, Sr, Ca, Mg e Al) & Zn & Valores \\
\hline Kaiser-Meyer-Olkin measure of sampling adequacy. & & 0.714 \\
\hline Bartlett's test of Sphericity & Approx. Chi-Square & 189.705 \\
\hline Commonalities & Significance & 0.001 \\
\hline & $\mathrm{Mn}$ & 0.710 \\
\hline & $\mathrm{Ba}$ & 0.708 \\
\cline { 2 - 3 } & $\mathrm{Sr}$ & 0.816 \\
\cline { 2 - 3 } & $\mathrm{Ca}$ & 0.712 \\
\hline
\end{tabular}

Table 5. Results of the variance matrix and component weights

\begin{tabular}{|c|c|c|c|c|c|c|}
\hline \multirow{2}{*}{ Components } & \multicolumn{3}{|c|}{ Initial eigenvalues } & \multicolumn{2}{c|}{ Components Matrix and Weights } \\
\cline { 2 - 7 } & Total & \% of variance & \% cumulative & Variables & PC 1 & PC 2 \\
\hline 1 & 3.538 & 58.965 & 58.965 & $\mathrm{Mn}$ & $\underline{0.768}$ & -0.291 \\
\hline 2 & 1.027 & 17.122 & 76.087 & $\mathrm{Ba}$ & $\underline{0.809}$ & -0.010 \\
\hline 3 & 0.749 & 12.480 & 88.567 & $\mathrm{Sr}$ & $\underline{0.900}$ & -0.082 \\
\hline 4 & 0.433 & 7.222 & 95.789 & $\mathrm{Ca}$ & $\underline{0.823}$ & 0.187 \\
\hline 5 & 0.154 & 2.567 & 98.356 & $\mathrm{Mg}$ & $\underline{0.853}$ & -0.135 \\
\hline 6 & 0.099 & 1.644 & 100.000 & $\mathrm{Al}$ & 0.284 & $\underline{0.939}$ \\
\hline
\end{tabular}

is highlighted factors that influence the levels in hair samples, such as the type of work, place and time of residence, and the type of food consumed (Zheng et al., 2010; Mehra and Thakur, 2016).

Multivariate Statistics: The Factor Analysis (FA) technique was adopted to provide data reduction and the indication of variables with important scores (components) in the sample set, based on previous research carried out on the application of the (Saleem et al., 2019; Njuguna et al., 2020). This approach allows a deeper and more comprehensive analysis of which variables are relevant in the neighborhood grouping. As suggested (Hair et al., 2009; Dini et al., 2014; Li et al., 2020; Kumar et al., 2019), the present study evaluated that the worked matrix, considering the initial selection of the variables $\mathrm{Mn}, \mathrm{Ba}, \mathrm{Sr}, \mathrm{Fe}, \mathrm{Ca}, \mathrm{Mg}, \mathrm{Al}$, and $\mathrm{Zn}$ did not present results of the KMO test (0.60), Bartlett's sphericity (0.05), and accumulated variance for two components with $(63.44 \%)$ satisfactory. As for commonality, weights were identified below 0.6 for $\mathrm{Fe}(0.268)$ and Zn (0.469), disagreeing with the established limit (Hair et al., 2009; Figueiredo Filho and Silva, 2010). Excluding the aforementioned metals, the sample set of variables that initially consisted of 9 was reduced to $6(\mathrm{Mn}, \mathrm{Ba}, \mathrm{Sr}, \mathrm{Ca}, \mathrm{Mg}$, and $\mathrm{Al})$ with results of 0.71 for the KMO test, 0.001 for Bartlett's sphericity, and $76.08 \%$ for accumulated variance in two components, making it an adjusted matrix with commonality above 0.7 as shown in Table 4 . Table 5 shows the information on accumulated variance and the component matrix with their respective weights. The first Principal Component (PC1) provided by the Factor Analysis presented a percentage of $58.96 \%$ of variance contained, whereas the second Principal Component (PC 2) contains $17.22 \%$, totaling $76.08 \%$ of explanation on the studied group and $23.91 \%$ of unexplained interaction. Another data extracted is related to the elements $\mathrm{Mn}, \mathrm{Ba}, \mathrm{Sr}, \mathrm{Ca}$, and $\mathrm{Mg}$ that lead to the explanation of the neighborhood grouping in the city of Altamira in $\mathrm{PC} \mathrm{1,} \mathrm{whereas} \mathrm{Al}$ is the main metal in the explanation of the group of associated neighborhoods in PC 2. Regarding the first component, $\mathrm{Hu}$ et al. (2019) report that elements such as $\mathrm{Ca}$ and $\mathrm{Mg}$ are considered biogenic or endogenous in the hair and for this reason, their concentrations are more susceptible to physiological processes such as ingestion of supplements, for example, than due to environmental contamination. Regarding $\mathrm{Mn}, \mathrm{Ba}$, and $\mathrm{Sr}$, their most common contamination pathways are exogenous. Previous studies report that these elements have a relatively high susceptibility to contamination from the environmental condition (Gellein et al. 2008; $\mathrm{Hu}$ et al., 2019). Although the absorption pathways are different, Ballesteros et al. (2017) suggest that the aforementioned elements tend to mutually associate in the organism due to chemical and biochemical factors, possibly influenced by age or sex, as reported in Madrid, Spain, and Italy (Senofonte et al., 2000). Figures 2 and 3 show the result of the groupings referring to the selected variables and the influence on the formation of clusters, respectively. In the first figure, there is the separation into two distinct groups, one formed by the elements $\mathrm{Mn}$, $\mathrm{Ba}, \mathrm{Ca}$, and $\mathrm{Sr}$ referring to $\mathrm{PC} 1$, which presents the highest explanatory percentage, and the other with only $\mathrm{Al}$ referring to PC 2. In Principal Component 1 , the association between the following neighborhoods stands out: Esplanada do Xingu, Açaizal, Aparecida, Centro, Jardim Independente I and II, Sudam I and II, Jardim Oriente, and Jardim dos Estados. 


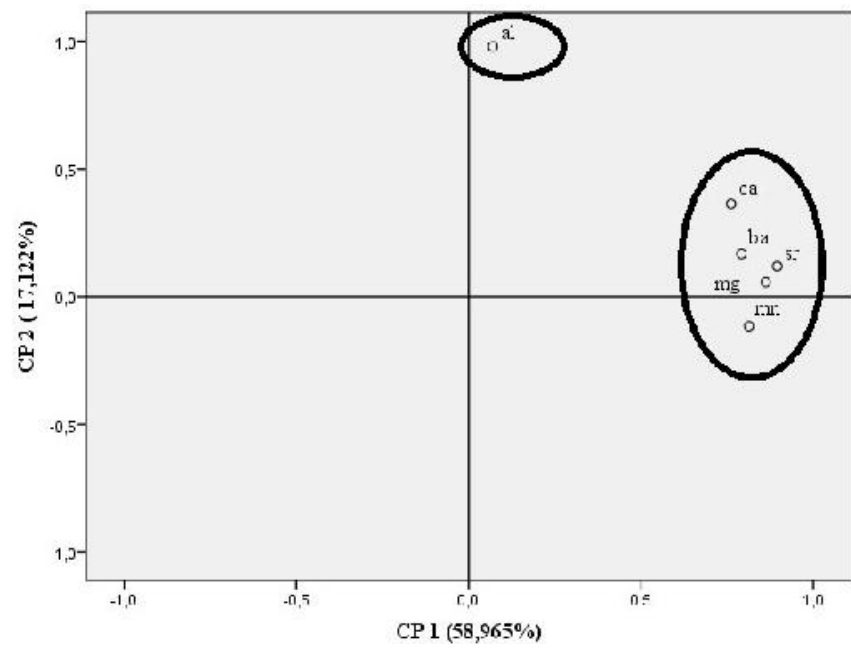

Figure 2. Illustration of the grouping according to the variables

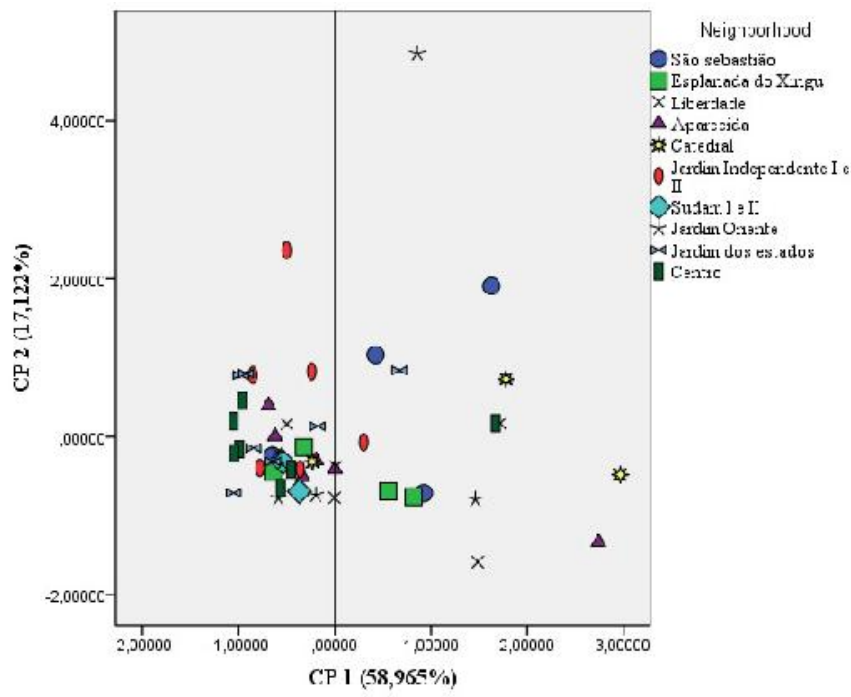

Figure 3. Illustration of the grouping according to the neighborhoods

Considerations about the behavior shown indicate that the presence of metals in resident individuals suggests special attention, above all, due to the presence of metals $\mathrm{Mn}$ and $\mathrm{Ba}$, as according to Skalny et al. (2015) and Irizar et al. (2019), can be explained by its frequent occurrence as an impurity of barite, which can increase the concentration in drinking water samples $(6.6 \mu \mathrm{g} / \mathrm{g})$ as occurred in Bangladesh and Russia. As for Mn, Gil and Hernández (2015) and Pragst et al. (2017) mention in their study that several factors are linked to high levels of this metal, such as smoking, living in industrial districts, and situations related to the emission of pollutants by traffic. $\mathrm{Ca}, \mathrm{Mg}$, and $\mathrm{Sr}$ generally do not exhibit any essential chronic toxicity condition capable of bringing any type of risk to human health. Principal Component 2 shows the grouping of São Sebastião and Catedral neighborhoods. Regarding PC 2, this relationship explains the risk to which these individuals are susceptible since the aluminum present in the hair is the result of exogenous exposure linked to the consumption of water without proper treatment, use of Al-containing products, or even direct exposure from contaminated food or water (Irizar et al., 2019). Tinkov et al. (2019) reinforce the presence of metal in the body associated with poor eating habits, which can alter the lipid metabolism of adipose tissue, contributing to obesity and metabolic syndrome, as occurred in Hong Kong. Krewski et al. (2007) add that epidemiological studies have reported a positive association between aluminum levels in drinking water and the risk of dementia with cognitive impairment.
Scientific counterpart to society: In view of the goals of the project that originated the present study, the findings were offered to the municipal health department of Altamira, which was responsible for planning actions aimed at this problem. Furthermore, the results were forwarded to the voluntary participants along with health guidelines for contamination prevention.

\section{CONCLUSIONS}

Biomonitoring indicates that the inhabitants of the neighborhoods surveyed in Altamira need special attention regarding the concentration of the trace elements evaluated in hair samples. The elements $\mathrm{Mn}, \mathrm{Ba}, \mathrm{Sr}, \mathrm{Ca}, \mathrm{Mg}$, and $\mathrm{Al}$ were the most relevant to explain the grouping between neighborhoods, with the aid of the univariate and multivariate statistics. Esplanada do Xingu, Açaizal, Aparecida, Centro, Independent Garden I and II, Sudam I and II, Jardim Oriente, and Jardim dos Estados were correlated due to similar values of $\mathrm{Mn}, \mathrm{Ba}, \mathrm{Sr}, \mathrm{Ca}$, and $\mathrm{Mg}$, with emphasis on the first two elements that have toxic action and need constant monitoring. Concerning São Sebastião and Catedral, the element responsible for its correlation is $\mathrm{Al}$, and for this reason, it is necessary to pay more attention to these residents due to the considerable level of toxicity that this element can cause to people. All the results served as a scientific support document for the health department of Altamira to promote actions to control and mitigate possible health problems.

\section{ACKNOWLEDGMENTS}

The authors would like to thank Eletronorte for the logistical support, ANEEL for the financing of this project, and CAPES and CNPq for undergraduate and graduate scholarships.

\section{REFERENCES}

Abdulrahman FI, Akan JC, Chellube ZM, Waziri M (2012). Levels of Heavy Metals in Human Hair and Nail Samples from Maiduguri Metropolis, Borno State, Nigeria. World Environ. 2:81-89.

Ainley V, Tsakiris M, Pollatos O, Schulz A, Herbert BM (2020). Comment on "Zamariola et al. (2018), Interoceptive Accuracy Scores are Problematic: Evidence from Simple Bivariate Correlations"- The empirical data base, the conceptual reasoning and the analysis behind this statement are misconceived and do not support the authors' conclusions. Biol. Psychol. 152:107870.

Ali MU, Liu G, Yousaf B, Ullah H, Abbas Q, Munir MAM, Irshad S (2019).Biomonitoring and health risks assessment of trace elements in various age- and gender-groups exposed to road dust in habitable urban-industrial areas of Hefei, China. Environ. Pollut. 244:809-817.

Ballesteros MTL, Serrano IN, Álvarez SI (2017). Reference levels of trace elements in hair samples from children and adolescents in Madrid, Spain. J. Trace Elem. Med. Biol. 43:113-120.

Batista BL, Rodrigues JL, Souza VCO, Barbosa Jr F (2009). A fast ultrasound-assisted extraction procedure for trace elements determination in hair samples by ICP-MS for forensic analysis Forensic Sci. Int. 192:88-93.

Charles B, Fredeen KJ. Perkin Elmer Corp, 1997.

Chojnacka K, Górecka H, Górecki H (2006). The influence of living habits and family relationships on element concentrations in human hair. Sci. Total Environ.366:612-620.

Dini AP, Alves DFDS, Oliveira HC, Guirardello EDB (2014). Validity and reliability of a pediatric patient classification instrument. Ver. Latino-Am. Enfermagem. 22:598603.

Drobyshev EJ, Solovyev ND, Ivanenko NB, Kombarova MY, Ganeev AA (2017).Trace element biomonitoring in hair of school children from a polluted area by sector field inductively coupled plasma mass spectrometry.J. Trace Elem. Med. Biol. 39:14-20.

Figueiredo Filho DB, Silva Jr JA (2010). Visão além do alcance: uma introdução à análise fatorial. Opin. Publica. 16:160-185. 
Filippini M, Greene WH, Kumar N, Martinez-Cruz AL (2018).A note on the different interpretation of the correlation parameters in the Bivariate Probit and the Recursive Bivariate Probit. Econ. Lett. 167:104-107.

Franco VDS, Souza EBD, Lima A (2018). Floods and social vulnerability: study on the Xingu river in Altamira / PA. Ambient. Soc. 21:e01573.

Gauthier C, Moran EF (2018). Public policy implementation and basic sanitation issues associated with hydroelectric projects in the Brazilian Amazon: Altamira and the Belo Monte dam. Geoforum. 97:10-21.

Gellein K, Lierhagen S, Brevik PS, Teigen M, Kaur P, Singh T, Flaten TP, Syversen T (2008). Trace Element Profiles in Single Strands of Human Hair Determined by HR-ICP-MS. Biol. Trace Elem. Res. 123:250-260.

Gibb H, O'Leary KG, Sarkar SK, Wang J, Liguori L, Rainis H, Smith KA, Chatterjee M (2016). Hair mercury concentrations in residents of Sundarban and Calcutta, India. Environ. Res. 150:616-621.

Gil F, Hernández AF (2015).Toxicological importance of human biomonitoring of metallic and metalloid elements in different biological samples. Food Chem. Toxicol.80:287-297.

Goullé JP, Mahieu L, Castermant J, Neveu N, Bonneau L, Lainé G, Bouige D, Lacroix C (2005). Forensic Sci. Int.

Gupta RC. (Ed.). Biomarkers in toxicology. Academic Press.

Hair JF, Black WC, Babin BJ, Anderson RE, Tatham RL (2009). Bookman editora.

Hu L, Fernandez DP, Cerling TE (2019).Trace element concentrations in horn: Endogenous levels in keratin and susceptibility to exogenous contamination. Chemosphere. 237:124443.

IBGE - INSTITUTO BRASILEIRO DE GEOGRAFIA E ESTATÍSTICA. Pesquisa Nacional por Amostra de Domicílios, 2014.

Irizar A, Gil F, Lertxundi A, Martín-Domingo MC, Urbieta N, Molinuevo A, Ibarluzea J, Basterrechea M, Aurrekoetxea JJ, Jiménez-Zabala A, Santa-Marina L (2019).Manganese levels in newborns' hair by maternal sociodemographic, dietary and environmental factors. Environ. Res. 170:92-100.

Katz SA, Chatt A (1988). Hair analysis: applications in the biomedical and environmental sciences. Wiley-VCH.

Kosanovic M, Jokanovic M (2011). Quantitative analysis of toxic and essential elements in human hair. Clinical validity of results. Environ. Monit. Assess. 174:635-643.

Krewski D, Yokel RA, Nieboer E, Borchelt D, Cohen J, Harry J, Kacew S, Lindsay J, Mahfouz AM, Rondeau V (2007). Human Health Risk Assessment for Aluminium, Aluminium Oxide, and Aluminium Hydroxide. J. Toxicol. Environ. Health. 10:1-269.

Kumar V, Parihar RD, Sharma A, Bakshi P, Sidhu GPS, Bali AS, Karaouzas I, Bhardwaj R, Thukral AKT, Gyasi-Agyei Y, Rodrigo-Comino J (2019). Global evaluation of heavy metal content in surface water bodies: A meta-analysis using heavy metal pollution indices and multivariate statistical analyses. Chemosphere. 236:124364.

Li Y, Yu Y, Zheng N, Hou S, Song X, Dong W (2020). Metallic elements in human hair from residents in smelting districts in northeast China: Environmental factors and differences in ingestion media. Environ. Res. 182:108914.

Macedo E (2016). O GARIMPO HIDRELÉTRICO: Impactos de belo Monte na cidade de Altamira e subsídios para reflexão sobre o complexo hidrelétrico do Tapajós. In: Alarcon DF, Millikan B, Torres M. (eds.). OCEKADI: hidrelétricas, conflitos socioambientais e resistência na Bacia do Tapajós. International Rivers Brasil. Brasília, DF.

Marcinek-Jacel M, Albińska J, Pawlaczyk A, Szynkowska MI (2017).The impact of demographic factors, behaviors and environmental exposure to mercury content in the hair of the population living in the region of Lodz (central Poland). Environ. Toxicol. Pharmacol. 55:196-201.

Mehra R, Thakur AS (2016). Relationship between lead, cadmium, zinc, manganese and iron in hair of environmentally exposed subjects. Arab. J. Chem. 9:S1214-S1217.
Miekeley N, Carneiro MD, Silveira CP (1998). How reliable are human hair reference intervals for trace elements? Sci. Total Environ. 218:9-17.

Miranda Neto JQD, Herrera JA (2016).Altamira-PA: novos papéis de centralidade e reestruturação urbana a partir da instalação da UHE Belo Monte. Confins. 28. Available in https://doi.org/10.4000/confins.11284

Njuguna SM, Onyango JA, Githaiga KB, Gituru RW, Yan X (2020). Application of multivariate statistical analysis and water quality index in health risk assessment by domestic use of river water. Case study of Tana River in Kenya. Process Saf. Environ. Prot. 133:149-158.

Pereira SDFP, Oliveira GRF, Oliveira JDS, Silva JDS, Sousa Junior PM (2009). Determinação espectrofotométrica do arsênio em solo da cidade de Santana-AP usando o método do dietilditiocarbamato de prata (SDDC) modificado. Acta Amaz. 39:953-960.

Pereira SF, De Lima MA, Freitas KH, Mescouto CS, Saraiva AF (2007).Environmental chemical study of the Murucupi river Barcarena, PA, Brazil impacted area for the aluminum production. Rev. Ambient. Água. 2:62-82.

Pozebon D, Dressler VL, Curtius AJ (1999). Análise de cabelo: uma revisão dos procedimentos para a determinação de elementos traço e aplicações. Quim. Nova. 22:838-846.

Pragst F, Stieglitz K, Runge H, Runow KD, Quig D, Osborne R, Runge C, Ariki J (2017). High concentrations of lead and barium in hair of the rural population caused by water pollution in the Thar Jath oilfields in South Sudan. Forensic Sci. Int. 274:99-106.

Robbins CR, Robbins CR (2012). Chemical and physical behavior of human hair.New York: Springer.

Rodushkin I, Axelsson MD (2000). Application of double focusing sector field ICP-MS for multielemental characterization of human hair and nails. Part II. A study of the inhabitants of northern Sweden. Sci. Total Environ. 262:21-36.

Saleem M, Iqbal J, Shah MH (2019). Seasonal variations, risk assessment and multivariate analysis of trace metals in the freshwater reservoirs of Pakistan. Chemosphere. 216:715-724.

Sela H, Karpas Z, Zoriy M, Pickhardt C, Becker JS (2007). Biomonitoring of hair samples by laser ablation inductively coupled plasma mass spectrometry (LA-ICP-MS). Int. J. Mass Spectrom. 261:199-207.

Semenova Y, Zhunussov Y, Pivina L, Abisheva A, Tinkov A, Belikhina T, Skalny A, Zhanaspayev M, Tolkyn Bulegenov T, Glushkova N, Lipikhina A, Dauletyarova M, Zhunussova T, Bjørklund $\mathrm{G}$ (2019). Trace element biomonitoring in hair and blood of occupationally unexposed population residing in polluted areas of East Kazakhstan and Pavlodar regions. J. Trace Elem. Med. Biol. 56:31-37.

Senofonte O, Violante N, Caroli S (2000).Assessment of reference values for elements in human hair of urban schoolboys. J. Trace Elem. Med. Biol. 14:6-13.

Skalny AV, Skalnaya MG, Tinkov AA, Serebryansky EP, Demidov VA, Lobanova YN, Grabeklis AR, Berezkina ES, Gryazeva IV, Skalny AA, Nikonorov AA (2015). Reference values of hair toxic trace elements content in occupationally non-exposed Russian population. Environ. Toxicol. Pharmacol. 40:18-21.

Skoog DA, West DM, Holler FJ, Crouch SR (2008). Fundamentos de Química Analítica.

Tinkov AA, Skalnaya MG, Aaseth J, Ajsuvakova OP, Aschner M, Skalny AV (2019). Aluminium levels in hair and urine are associated with overweight and obesity in a non-occupationally exposed population. J. Trace Elem. Med. Biol. 56:139-145.

Tipple BJ, Chau T, Chesson LA, Fernandez DP, Ehleringer JR (2013). Isolation of strontium pools and isotope ratios in modern human hair. Anal. Chim. Acta. 798:64-73.

Wang X, Ning Y, Zhang P, Li C, Zhou R, Guo X (2019). Hair multibioelement profile of Kashin-Beck disease in the endemic regions of China. J. Trace Elem. Med. Biol. 54:79-97.

Zheng N, Liu J, Wang Q, Liang Z (2010). Health risk assessment of heavy metal exposure to street dust in the zinc smelting district, Northeast of China. Sci. Total Environ. 408:726-733. 